The stretch response of the upper eyclid may form part of the intrinsic pattern of function of antigravity muscles during consciousness. It may be considered advantageous during the wakeful state to limit the amount of control referred to the conscious level, by the provision of local controls (stretch roflexes). We may regard the oyelid stretch reflex to be in this category, and to provide somo degroo of control of position at a low level, while only rolatively important decisions are referred to higher brain levols for conscious consideration.

D. W. KENNARD

G. L. SMYTH

Modical Psychology Laboratory, University of Cambridge.

'Glaser, G. H., and Kennard, 1). W., Nature, 193, 1110 (1962).

'Whitteridge, D., in Hundbook of Physiology, Sect. 1, edit. by Ficld, J., Magoun, N. W., and Hall, V. E,, 2, 1094 (Amer. Physiol. Brindley, G. S., and Merton,

. A., J. Physiol., 153, 127 (1960)

- Kennard, D. W., and Smyth, G. L. (in course of pullication).

\section{Perception of Topographical Information (with Reference to Road Signs)}

An experimental study has compared six layouts of advance road direction signs. This communication is concerned with three of these, at present displayed in Great Britain, the Continent and the United States. On the first two designs, a road intersection is represented by a diagram on the display, road numbers and place-names are enclosed in roctangular boxes on the British layout, without boxes on the Continontal design. On the American display tho dostinations are listed and short arrows at the side indicate direction. The distance legibility is greatest for the American type, then the Continental, and tho British signs are least legible whon signs are compared on backboards of equal area ${ }^{1}$. The order appeared to be determined by the sizo of lettering. The prosent experiments tested the effect of the differenco in the displays on accuracy and specd of interpretation.

Signs describing a route with junctions of difforent comploxity were drawn in each of the layouts. Subjects sat $9 \mathrm{ft}$. from a scroon and off-set $1.4 \mathrm{ft}$. to the right. A projection tachistoscope displayod the signs, with black on white contrast, $1 / 10$ th to scale for intervals ranging from 0.5 to 2 sec. This gave some similitude to the visual angle at which drivers view signs. Subjects responded to the signs either by drawing the direction necessary to attain a previously designated destination, or by moving a control stick. Throughout the experiment they performed a compensatory tracking task as a substitute for driving. with the tracking display set normal to the subject. Performance was measured by: $(a)$ response-time between the presentation of the sign and tho subject's response with the control stick; $(b)$ orrors of drawn directional movement; $(c)$ indirect effects of the sign layouts on an error score on the tracking task. In separate oxperiments, signs in three layouts, selected from all those tosted, wero compared. The sign layouts were presented in a counter-balanced ordor and a subject followed the route throo times.

In a subsidiary experiment, signs were briefly exposed to subjects who were roquired to draw a diagram of tho junction represented immediately afterwards, and indicate tho direction necessary to reach a destination. 'The diagrams were scored for accuracy.
Table 1. ScORES on RESPONSW MFAsURES TO DIRECTION SIGNS

$\begin{array}{lccccc}\begin{array}{c}\text { Response } \\ \text { Incasures }\end{array} & \text { British } & \begin{array}{c}\text { Layout } \\ \text { Continental }\end{array} & \text { American } & \begin{array}{c}\text { No. of } \\ \text { signs per } \\ \text { layout }\end{array} & \begin{array}{c}\text { No. of } \\ \text { subjects } \\ \text { per cell }\end{array} \\ \begin{array}{c}\text { Mean log } \\ \text { response time }\end{array} & 2 \cdot 2132 & 2 \cdot 1291 & 2 \cdot 1365 & 6 & 18 \\ \begin{array}{c}\text { Errors of direc- } \\ \text { tional movement }\end{array} & 43 & 26 & 17 & 9 & 27 \\ \begin{array}{c}\text { Frrors of repro- } \\ \text { duction }\end{array} & 36 & 39 & 70 & 12 & 12\end{array}$

The tracking task scoros showed no differenco between layouts. Table 1 shows the results of the other moasures; significanco was tested by analysis of varianco.

There were more errors of directional movement and a longer response time to the British layout. Caution is required in intorpreting the latter result as response time was partially dotermined by interaction effects between the British layout and the others with which it was compared. Errors of reproduction were greatest on the American layout, although on all layout orrors wore more numerous on complex signs. On the American layout four-fifths of the atternpts at reproducing the complex signs were unsuccessful.

These results showed that it was possible to scan and select a direction from a Continental or American sign with almost equal facility, but on the latter layout the numerous errors of reproduction on the complex signs demonstrated that the topographical displays convey an erronoous message about the layout of the crossroads the observer will meet. However, before simple junctions, the American list layout may be optimal as it permits larger lettering. It was concluded that before simple junctions there are advantages in displaying the Continental or Amorican layouts; before complex junctions, the Continontal design with a diagram of tho approaching junction is desirable.

Part of the problem of designing topographical displays is to emphasize significant details to aid visual resolution, but cognitive processes of interpretation are also important. The individual, in route finding, has to locate his own geographical position and to have the intention of proceeding to another known position. In doing so, he has the aid of symbolic representations in the form of topographical displays. The individual has to match the symbolic representation with the geographical layout, either directly or from memory of the representation, which requires the selective use of environmental cues. Bartlett ${ }^{2}$ has described the ideational contont of direction finding from road signs, placing emphasis on the general anticipatory function of the symbols. The present results suggest that not only may the symbols be changed to aid discrimination, but the form of the layout may reduco conceptual work. Emphasis on discriminability and the presentation of optimum configuration or 'Gestalten' can present different design problems which are not always easy to reconcile.

The work was carried out in collaboration with the Road Rosearch Laboratory. I. thank Mr. J. W. Whitfiold for directing the work.

Medical Rosearch Council,

$$
\text { J. WALKER }
$$

Industrial Psychology Research Unit, Psychology Department, University College, London, W.C.1.

"Moore, R. I... The Design of Traffe Signs. International Study Week in Trafic Fingineering. Copenhagen (World Touring and Automob

sartlett, F. C., Thinking (George Allen and Unwin, London, 1958). 